\title{
Iptek bagi Masyarakat Kelurahan Lere dalam Pengembangan Usaha Berbahan Baku Lamale (Penaeus sp.)
}

\section{(The Program of Science and Technology for Community to Develop the Lamale (Penaeus sp.) based Product Business at Lere Village)}

\author{
Wendy Alexander Tanod ${ }^{1,2}{ }^{*}$, Anita Treisya Aristawati' ${ }^{1}$, Deddy Wahyudi ${ }^{1}$, Yeldi S. Adel ${ }^{1}$ \\ 1 Sekolah Tinggi Perikanan dan Kelautan Palu (STPL) \\ Jl. Soekarno Hatta KM 6 (Kampus Madani) Kota Palu, Sulawesi Tengah 94119. \\ 2 Program Pascasarjana, Fakultas Perikanan dan Ilmu Kelautan, Universitas Brawijaya Malang, \\ Jl. Veteran No. 16 Kota Malang, Jawa Timur 65145. \\ *Penulis Korespondensi: wendytanod@stplpalu.ac.id \\ Diterima Agustus 2017/Dsetujui November 2018
}

\begin{abstract}
ABSTRAK
Bahari Jaya 2 dan Sehati merupakan kelompok nelayan mitra yang berlokasi di Kelurahan Lere, Kecamatan Palu Barat, Kota Palu, Provinsi Sulawesi Tengah. Pada umumnya, hasil tangkapan dari kedua kelompok nelayan mitra, yaitu udang kecil (Penaeus sp.) dengan nama lokal lamale. Tujuan dari kegiatan ini adalah meningkatkan keterampilan dan pengetahuan anggota kelompok nelayan Bahari Jaya 2 dan kelompok nelayan Sehati, agar mampu menjalankan usaha olahan berbahan baku udang lamale. Kegiatan dilakukan April-November 2015. Metode pelaksanaan, yaitu wawancara, penyebaran dan pengisian kuesioner dilakukan dalam tahap penentuan masalah; tahap presentasi, negosiasi, dan penetapan program; serta tahap fasilitasi dan pendampingan mitra. Indikator keberhasilan kegiatan adalah kedua kelompok mitra dapat menjalankan usaha pengolahan secara berkelanjutan. Hasil yang telah dicapai kedua kelompok mitra adalah 1) Dapat mengolah lamale menjadi mi dan nugget, 2) Telah memiliki pengetahuan prospek usaha penjualan mi dan nugget lamale, 3) Telah memiliki pengetahuan tentang quality control, manajemen mutu, dan sanitasi dalam usaha pengolahan, 4) Memiliki pengetahuan tentang komposisi gizi dari mi dan nugget lamale; dan 5) Kedua kelompok mitra dapat mengelola usaha penjualan yang berorientasi pada profit.
\end{abstract}

Kata kunci: IbM, lamale, mi, nugget, udang

\section{ABSTRACT}

Bahari Jaya 2 and Sehati are partner fishermen groups located in Lere urban village, West Palu District, Palu, Central Sulawesi. In general, the catches from the two partner fishing groups are small shrimp (Penaeus sp.), with local names lamale. The purpose of IbM activities is to improve the skills and knowledge of members of the Bahari Jaya 2 and Sehati fishing group, to be able to run a processed business made from raw shrimp lamale. The projects carried out from April to November 2015. The method consists of 3 stages: 1) The stage of problem determination; 2) Stage presentation, negotiation and programming; and 3) Facilitation and mentoring of partners. The success indicator of this project; namely the two partner groups able to sustainably run a processing business. The results achieved by the two partner groups, i.e., 1) Partners can process lamale into noodles and nuggets, 2) Partners know business prospects for lamale noodle and nuggets, 3) Partners know quality control, quality management and sanitation in processing business, 4) Partners know the nutritional composition of the lamale noodle and nuggets, 5) Both groups of partners can manage profit-oriented sales businesses.

Keywords: IbM, lamale, noddle, nugget, shrimp

\section{PENDAHULUAN}

Kegiatan pengabdian ini dilaksanakan di Kelurahan Lere, Kecamatan Palu Barat, Kota Palu. Kelurahan Lere merupakan salah satu kelurahan yang sebagian masyarakatnya berprofesi sebagai nelayan. Daerah ini memiliki potensi perikanan khususnya udang kecil yang memiliki nama lokal lamale (Kanangadju et al. 1989) (Gambar 1). Udang ini memiliki sifat musiman, yang terlihat dari aktivitas nelayan yang melakukan penangkapan yang optimal dilakukan pada musim penghujan (BPS Kota Palu 2010). Pada umumnya udang rebon dibuat terasi udang dan merupakan produk perikanan yang umum dipakai sebagai pelengkap masakan (Anggo et al. 2014). 

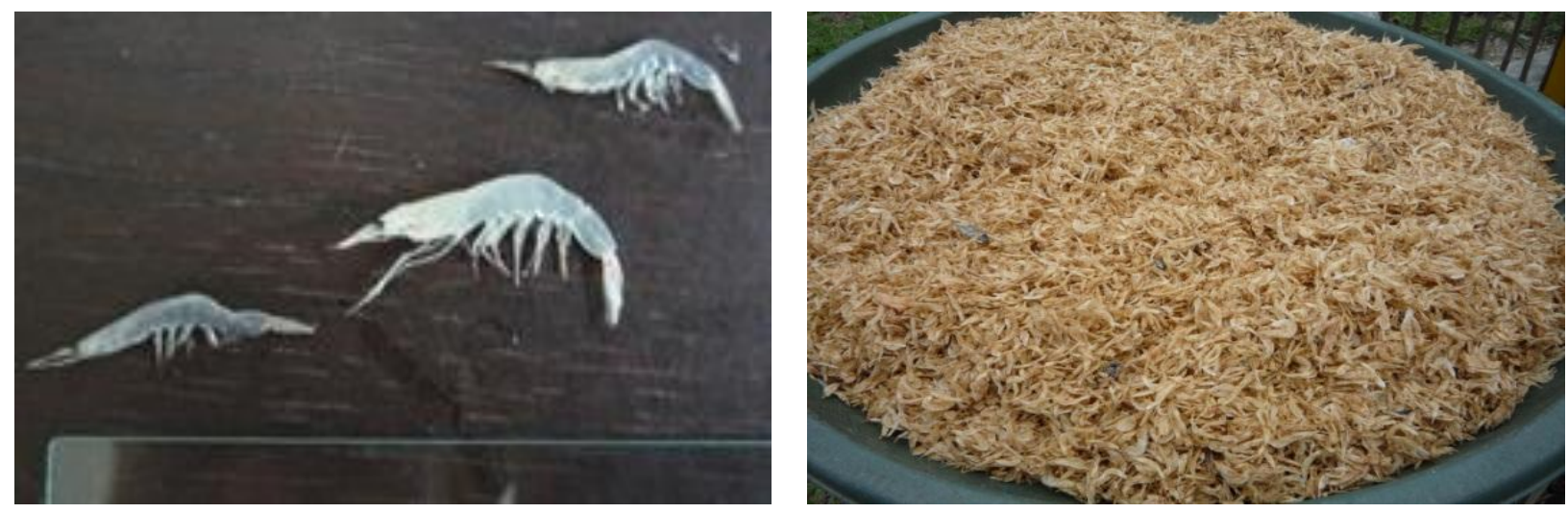

Gambar 1 Bentuk udang lamale.

Udang lamale ini memiliki kalsium yang tinggi 100 g udang segar mengandung $757 \mathrm{mg}$ kalsium, sedangkan dalam 100 g udang yang sudah dikeringkan sebanyak $2.306 \mathrm{mg}$, sehingga mengonsumsi udang sangat baik dalam mencegah osteoporosis. Selain itu, udang juga mempunyai kandungan fosfor yang cukup tinggi (Amri \& Kanna 2008).

Berdasarkan hasil survei awal, rata-rata dalam setiap penangkapan udang lamale nelayan mendapatkan sekitar $25 \mathrm{~kg}$ dalam sehari (dengan kegiatan penangkapan antara 8-12 jam). Dalam seminggu nelayan mendapatkan udang lamale sekitar $150 \mathrm{~kg}$. Pemanfaatan udang lamale di daerah ini belum dilakukan secara optimal. Hasil tangkapan udang lamale langsung dijual kepada pengumpul atau konsumen baik dalam bentuk basah maupun yang sudah dikeringkan. Harga jual per kilogram udang lamale basah berkisar antara Rp 15.000-20.000 (DKP Propinsi Sulawesi Tengah 2010).

Berdasarkan hasil wawancara awal dengan nelayan di Kelurahan Lere, pada umumnya udang lamale merupakan hasil tangkapan utama dari nelayan di Kelurahan Lere pada musim penghujan. Kegiatan penangkapan udang lamale ini, merupakan mata pencaharian yang turun temurun atau merupakan warisan dari orang tua (Mardjudo 2011).

Jumlah hasil tangkapan lamale di Kelurahan Lere cukup berlimpah, namun tingkat kesejahteraan nelayan masih rendah. Menurut wawancara dari nelayan setempat, pelatihan dari pemerintah setempat tentang pengolahan menggunakan bahan baku udang lamale masih sangat kurang. Kelompok nelayan Kelurahan Lere tidak mengetahui teknologi pengolahan untuk meningkatkan nilai jual dari udang lamale, selain teknik pengeringan.

Tim memandang pelatihan prospek dan analisis usaha olahan udang lamale penting dilakukan dalam kegiatan ipteks bagi masyarakat di Kelurahan Lere. Pelatihan ini memberikan pemahaman mengenai strategi pengembangan agribisnis perikanan. Agribisnis adalah suatu kesatuan yang utuh mulai proses produksi, pengolahan hasil, pemasaran dan aktivitas lain yang terkait dengan segala kegiatan pertanian (Soekartawi 2005). Pada kegiatan ini, tim memilih melakukan pendampingan dan pelatihan pada 2 kelompok nelayan mitra yang berada di Kelurahan Lere, yakni kelompok nelayan Bahari Jaya 2 dan kelompok nelayan Sehati. Terdapat 6 kelompok nelayan aktif di Kelurahan Lere, akan tetapi berdasarkan hasil survei, 2 kelompok nelayan mitra merupakan kelompok nelayan yang melakukan hampir $70 \%$ penangkapan dan penjualan lamale di perairan Teluk Palu (Hanifah 2015).

Pengetahuan mengenai teknik pengolahan juga diberikan dengan tujuan meningkatkan nilai jual udang lamale. Setelah olahan udang lamale dipahami oleh mitra, maka tim pengabdian juga memberikan pelatihan tentang teknik pemasaran hasil olahan udang lamale. Pemasaran merupakan salah satu kegiatan pokok yang harus dilakukan oleh para pengusaha termasuk para nelayan dalam usahanya untuk mempertahankan kelangsungan hidupnya. Berhasil tidaknya usaha tersebut sangat tergantung pada keahliannya di bidang pemasaran, produksi, keuangan, dan sumber daya manusia (Firdaus 2008). Diharapkan melalui kegiatan Ipteks bagi Masyarakat (IbM) ini tingkat kesejahteraan mitra dapat meningkat dari kondisi semula. Tujuan dari kegiatan IbM ini adalah meningkatkan keterampilan dan pengetahuan anggota kelompok nelayan Bahari Jaya 2 dan kelompok nelayan Sehati, agar mampu menjalankan usaha olahan berbahan baku udang lamale. Luaran dalam kegiatan ini dapat dilihat pada Tabel 1. 
Tabel 1 Luaran kegiatan IbM di Kelurahan Lere

\begin{tabular}{ll}
\hline \multicolumn{1}{c}{ Jenis produk } & \multicolumn{1}{c}{ Mitra } \\
\hline Pengolahan & Kedua mitra menghasilkan mi dan nugget berbahan baku udang lamale \\
Kemampuan & Kedua mitra memiliki kemampuan mengolah udang lamale menjadi mi dan nugget \\
& yang berkualitas \\
Pengetahuan & Kedua mitra memiliki pengetahuan prospek usaha penjualan mi dan nugget udang \\
& lamale \\
& - Kedua mitra memiliki pengetahuan quality control, manajemen mutu, dan sanitasi \\
Manajemen dan & - Manajemen mitra memiliki pengetahuan tentang gizi dari udang lamale \\
pemasaran & - Kedua mitra dapat memasarkan produk yang telah dibuat, sehingga mendapatkan \\
& keuntungan.
\end{tabular}

\section{METODE PELAKSANAAN KEGIATAN}

\section{Waktu dan Tempat}

Kegiatan IbM ini dilaksanakan di Kelurahan Lere, Kecamatan Palu Barat, Kota Palu, Provinsi Sulawesi Tengah dan dilakukan mulai bulan April-November 2015. Kelompok mitra adalah kelompok nelayan Bahari Jaya 2 dan Sehati.

\section{Tahapan Kegiatan}

Metode kegiatan IbM ini dilakukan dalam beberapa tahap, yaitu tahap penentuan masalah, tahap presentasi, negosiasi, dan penetapan program, serta tahap fasilitasi dan pendampingan mitra.

\section{- Tahap penentuan masalah}

Pada tahap ini ditempuh melalui metode wawancara dan penyebaran serta pengisian kuisioner, sehingga dapat diperoleh pokok permasalahan yang dihadapi dari masing-masing anggota kelompok mitra. Melalui metode ini, didapatkan data awal yang menggambarkan situasi dan permasalahan utama yang dihadapi kedua kelompok mitra dalam kegiatan iptek bagi masyarakat.

\section{- Tahap presentasi, negosiasi, dan} penetapan program

Pada tahap ini disampaikan ide/gagasan tentang program IbM kepada pihak kelompok mitra Bahari Jaya 2 dan Sehati, untuk meyakinkan bahwa program yang disampaikan memiliki nilai strategis dan berdampak positif pada peningkatan kesejahteraan anggota kelompok nelayan. Hasil negosiasi menjadi landasan kesepakatan untuk berkomitmen dalam sebuah kerja sama pengembangan program iptek bagi masyarakat.

\section{- Tahap fasilitasi dan pendampingan mitra}

Pada tahap ini fasilitasi dilakukan melalui pelatihan. Pelatihan yang bersifat peningkatan pengetahuan, peningkatan kemampuan (pengolahan, manajemen, dan pemasaran), pendekatan sharing, dan diskusi. Pelatihan pertama prospek dan analisis usaha. Pelatihan kedua pembuatan olahan berbahan baku lamale. Pendampingan dilakukan setelah pelatihan pembuatan mi dan nugget sebagai pengawasan bahwa hasil pelatihan dipraktikkan dan diterapkan berkelanjutan.

Pendampingan tahap penjualan dilakukan selama 3 bulan, dengan tempat penjualan di kawasan penjualan hasil dan produk perikanan Pantai Talise, serta target konsumen adalah para pembeli yang melakukan transaksi di Pasar Talise. Selama penjualan juga dilakukan monitoring dan evaluasi (apakah sudah sesuai dengan prosedur sewaktu tahap fasilitasi dan pendampingan). Evaluasi dilakukan dengan menganalisis pembukuan sederhana dari kedua mitra.

\section{HASIL DAN PEMBAHASAN}

\section{Hasil Kegiatan Penentuan Masalah dengan Kelompok Mitra}

Hasil dari kegiatan diskusi ini menunjukkan bahwa kedua mitra mengapresiasi kegiatan pelatihan dan pendampingan. Hal ini terlihat sekitar 10 dari 15 jumlah anggota dari kedua kelompok mitra hadir dan keaktifan anggota kelompok mitra antusias dalam tahap penentuan masalah. Menurut ketua kelompok kedua mitra, selama ini kelompok nelayan penangkap lamale belum pernah diberikan pelatihan dan pendampingan dalam mengolah dan mengembangkan usaha berbahan baku lamale. Padahal usaha 
penangkapan lamale merupakan usaha yang telah berlangsung turun temurun. Oleh karena itu, kegiatan ini sangat didukung sebagai upaya dalam peningkatan kualitas sumber daya manusia dalam mengolah lamale. Dari diskusi didapat permasalahan yang dihadapi kedua mitra, yaitu kedua mitra tidak memiliki keterampilan untuk mengolah hasil tangkapan lamale selain cara pengeringan dan kedua mitra kurang mengetahui sistem manajemen dan pemasaran produk perikanan untuk meningkatkan pendapatan.

\section{Hasil Kegiatan Tahap Presentasi, Negosiasi, dan Penetapan Program}

Setelah dipetakan permasalahan yang dihadapi oleh kedua mitra tahapan selanjutnya adalah tahap presentasi rancangan kegiatan yang akan dilakukan. Berdasarkan permasalahan yang dihadapi mitra, tim merancang kegiatan pelatihan membuat olahan berbahan baku lamale. Tiap kelompok mendapatkan jenis produk olahan yang berbeda. Selain itu, kegiatan pelatihan manajemen usaha pengolahan juga dilakukan. Pada tahapan ini, banyak masukan kegiatan dari anggota kelompok mitra, sehingga dengan memerhatikan jumlah dana dan waktu yang tersedia, maka negosiasi dilakukan oleh tim, agar target dan luaran dapat tercapai sesuai waktu 8 bulan yang disediakan. Hasil diskusi menyepakati program/kegiatan yang akan dilakukan dalam kegiatan iptek bagi masyarakat ini adalah kelompok Bahari Jaya 2 dilakukan pelatihan analisis usaha dan pembuatan produk mi lamale. Kelompok sehati mendapatkan pelatihan analisis usaha dan pembuatan produk nugget lamale. Produk olahan yang diajarkan sengaja diberikan berbeda, dengan tujuan tidak terjadi persaingan penjualan antara kedua kelompok. Selain itu, pada kedua kelompok juga diberikan pelatihan tentang gizi produk lamale, manajemen usaha, serta sanitasi dan hygiene usaha pengolahan.

\section{Tahap Fasilitasi}

Tahap ini diawali dengan pelatihan prospek dan analisis usaha produk berbahan baku lamale. Analisis usaha berdasarkan petunjuk (Muhamadjen 2008; Sundari 2011). Pelatihan prospek dan analisis usaha dihadiri perwakilan dari tiap-tiap kelompok mitra yang berjumlah 5 orang (Gambar 2). Pada kelompok nelayan Bahari Jaya 2 dilakukan pelatihan memproduksi mi lamale. Analisis komponen biaya usaha produk mi lamale dapat dilihat pada Tabel 2 .
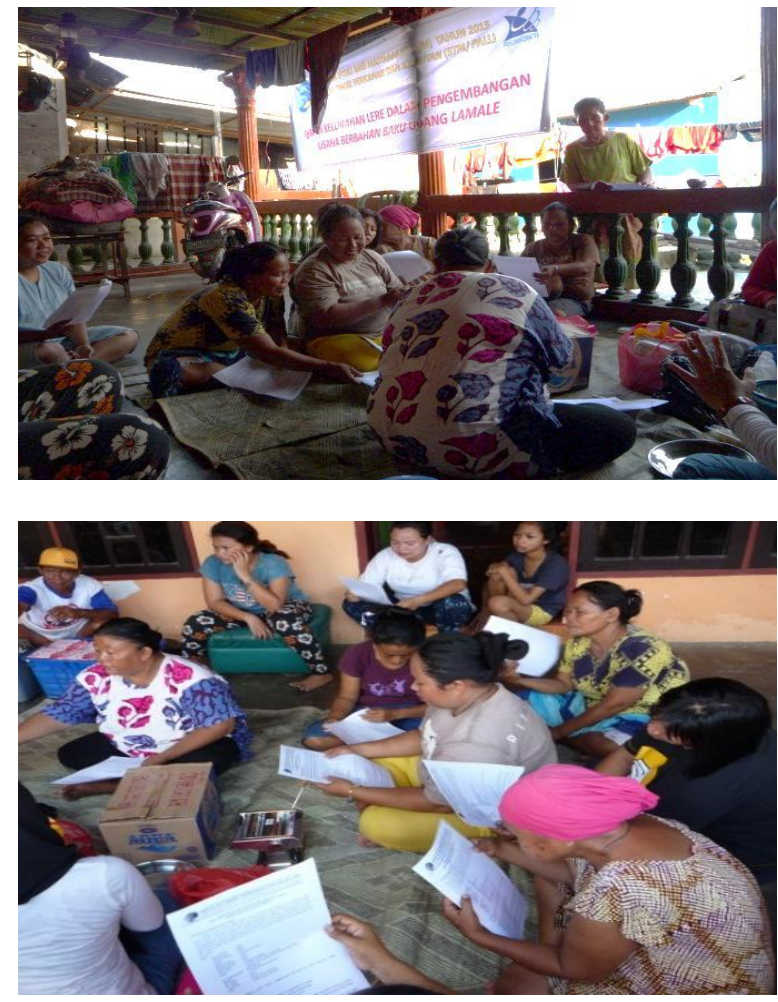

Gambar 2 Pelatihan prospek dan analisis usaha.

Analisis komponen biaya pada Tabel 2 dapat dihitung hasil analisis kelayakan usaha mi lamale diperoleh nilai laba bersih Rp 222.560/bulan, dengan $B C$ ratio 1,08 (Bila $B C$ ratio $<1$ usaha tidak layak untuk dijalankan, $\mathrm{BC}$ ratio $>1$ usaha tersebut menguntungkan sehingga usaha dapat dilanjutkan). Margin keuntungan masih relatif kecil, namun memberikan alternatif keuntungan dari hanya menjual produk kasar atau setengah jadi. Titik impas (BEP) produksi sebesar 103 kemasan/bulan, BEP harga Rp 20.719,52/ kemasan, dan Payback Period (PBP) 0,65 tahun, yang artinya modal investasi usaha yang digunakan akan kembali dalam jangka waktu sekitar 7 bulan 8 hari. Dari data analisis kelayakan usaha dapat disimpulkan bahwa usaha produksi mi lamale dapat dikatakan layak (feasible) untuk dilaksanakan.

Pelatihan memproduksi nugget lamale dilakukan pada kelompok nelayan Sehati. Analisis komponen biaya usaha produk nugget lamale dapat dilihat pada Tabel 3. Berdasarkan Tabel 3 dapat dihitung hasil analisis kelayakan usaha nugget lamale diperoleh nilai laba bersih Rp 353.110/bulan, BC ratio 1,1, titik impas (BEP) produksi sebesar 163 kemasan/bulan, BEP harga Rp 17.134/kemasan, dan Payback Period (PBP) 0,58 tahun, yang artinya modal investasi usaha yang digunakan akan kembali dalam jangka waktu 6 bulan 9 hari. Berdasarkan data analisis kelayakan usaha di atas dapat disimpulkan 
Tabel 2 Analisis komponen biaya usaha mi lamale

\begin{tabular}{|c|c|c|c|c|}
\hline \multicolumn{5}{|l|}{ Investasi awal } \\
\hline Ura & & Jumlah & Harga satuan (Rp) & Jumlah (Rp) \\
\hline Kompor hock & & 1 & 275.000 & 275.000 \\
\hline Gilingan mi & & 1 & 355.000 & 355.000 \\
\hline Loyang & & 2 & 20.000 & 40.000 \\
\hline Baki bulat & & 3 & 30.000 & 90.000 \\
\hline Wajan & & 1 & 110.000 & 110.000 \\
\hline Sealer & & 1 & 950.000 & 950.000 \\
\hline \multicolumn{3}{|c|}{ Jumlah investasi awal } & & 1.820 .000 \\
\hline \multicolumn{5}{|l|}{ Biaya produksi } \\
\hline \multicolumn{5}{|l|}{ 1. Biaya tetap/bulan } \\
\hline \multicolumn{3}{|c|}{ Uraian } & \multicolumn{2}{|c|}{ Jumlah (Rp) } \\
\hline \multicolumn{3}{|c|}{ Izin usaha 0,5\%/bulan dari investasi } & \multicolumn{2}{|c|}{9.100} \\
\hline \multicolumn{3}{|c|}{ Penyusutan $0,5 \% /$ bulan dari investasi } & \multicolumn{2}{|c|}{9.100} \\
\hline \multicolumn{3}{|c|}{ Bunga modal $2 \%$ /bulan dari investasi } & \multicolumn{2}{|c|}{36.400} \\
\hline \multicolumn{3}{|c|}{ Perawatan peralatan dan mesin $1 \%$ /bulan dari investasi } & \multicolumn{2}{|c|}{18.200} \\
\hline \multicolumn{3}{|c|}{ Tenaga kerja Rp 400.000/org/bulan $\times 2$ org } & \multicolumn{2}{|c|}{800.000} \\
\hline Jur & a tetap/bu & & \multicolumn{2}{|c|}{872.800} \\
\hline \multicolumn{5}{|c|}{ 2. Biaya tidak tetap/bulan (100 kg mi) } \\
\hline Uraian & Jumlah & Satuan & Harga Satuan (Rp) & Jumlah (Rp) \\
\hline Tepung udang lamale & 2 & $\mathrm{~kg}$ & 20.000 & 40.000 \\
\hline Tepung terigu & 55 & $\mathrm{~kg}$ & 15.000 & 825.000 \\
\hline Tepung tapioka & 45 & $\mathrm{~kg}$ & 8.000 & 360.000 \\
\hline Telur & 35 & Butir & 1.500 & 52.500 \\
\hline Garam & 7 & bungkus & 3.000 & 21.000 \\
\hline Minyak goreng & 10 & $\mathrm{~kg}$ & 12.000 & 120.000 \\
\hline Soda kue & 5 & bungkus & 5.000 & 25.000 \\
\hline \multicolumn{3}{|c|}{$\begin{array}{l}\text { Biaya lain-lain } 0,2 \% \text { /bulan } \\
\text { dari investasi }\end{array}$} & 3.640 & 3.640 \\
\hline Beban Listrik & 1 & bulan & 50.000 & 50.000 \\
\hline Beban transportasi & 1 & bulan & 20.000 & 20.000 \\
\hline Beban promosi & 1 & bulan & 50.000 & 50.000 \\
\hline Beban pengemasan & 1 & bulan & 150.000 & 150.000 \\
\hline \multicolumn{3}{|c|}{ Jumlah biaya tidak tetap/bulan } & & 1.717 .140 \\
\hline \multicolumn{3}{|c|}{ Total biaya produksi/bulan } & & 2.589 .940 \\
\hline \multicolumn{5}{|l|}{ 3. Proyeksi laba rugi } \\
\hline \multicolumn{5}{|c|}{ Produksi mi (125/kemasan $800 \mathrm{~g})$} \\
\hline \multicolumn{3}{|c|}{ Uraian } & \multicolumn{2}{|c|}{ Jumlah (Rp) } \\
\hline \multicolumn{3}{|c|}{ Pendapatan 125 kemasan @ Rp 25.000 (dalam 1 bulan) } & 3.1 & \\
\hline Biaya produksi/bulan & & & 2.5 & \\
\hline Pajak 10\% & & & & \\
\hline Laba/bulan (poir & $2-$ point 3 & & & \\
\hline
\end{tabular}

bahwa usaha produksi nugget lamale dapat dikatakan layak (feasible) untuk dijalankan.

Selanjutnya, dilakukan pelatihan pembuatan olahan berbahan baku lamale. Gambar 3 menunjukkan pelatihan pembuatan mi lamale pada kelompok Bahari Jaya 2 dan nugget lamale pada kelompok Sehati. Pelatihan diawali dengan demo produk olahan mi dan nugget, kemudian diikuti oleh praktik yang dilakukan oleh masing-masing kelompok. Hasil produk olahan kemudian dikemas dan siap dipasarkan di gerai atau kios kelompok mitra. Selama pelatihan juga diberikan pengetahuan mengenai komposisi gizi produk mi dan nugget lamale dibandingkan dengan SNI mi dan nugget (Tabel 4).

Hasil analisis gizi menunjukkan bahwa mi dan nugget yang telah diproduksi memenuhi standar mutu mi basah (BSN 1992) dan nugget (BSN 2002) sesuai Standar Nasional Indonesia. Menurut Astawan (1999), umumnya komposisi kimia mi basah per $100 \mathrm{~g}$ bahan, yaitu energi $86 \mathrm{kal}$, protein $0,6 \mathrm{~g}$, lemak $3,3 \mathrm{~g}$, karbohidrat $14 \mathrm{~g}$, kalsium $13 \mathrm{mg}$, besi 0,8 mg, dan air $80 \mathrm{mg}$. Hasil analisis mi lamale menunjukkan bahwa kadar lemak lebih tinggi dari kadar lemak mi pada umumnya, hal ini disebabkan penambahan udang yang mengandung asam lemak tak jenuh. 
Tabel 3 Analisis komponen biaya usaha nugget lamale

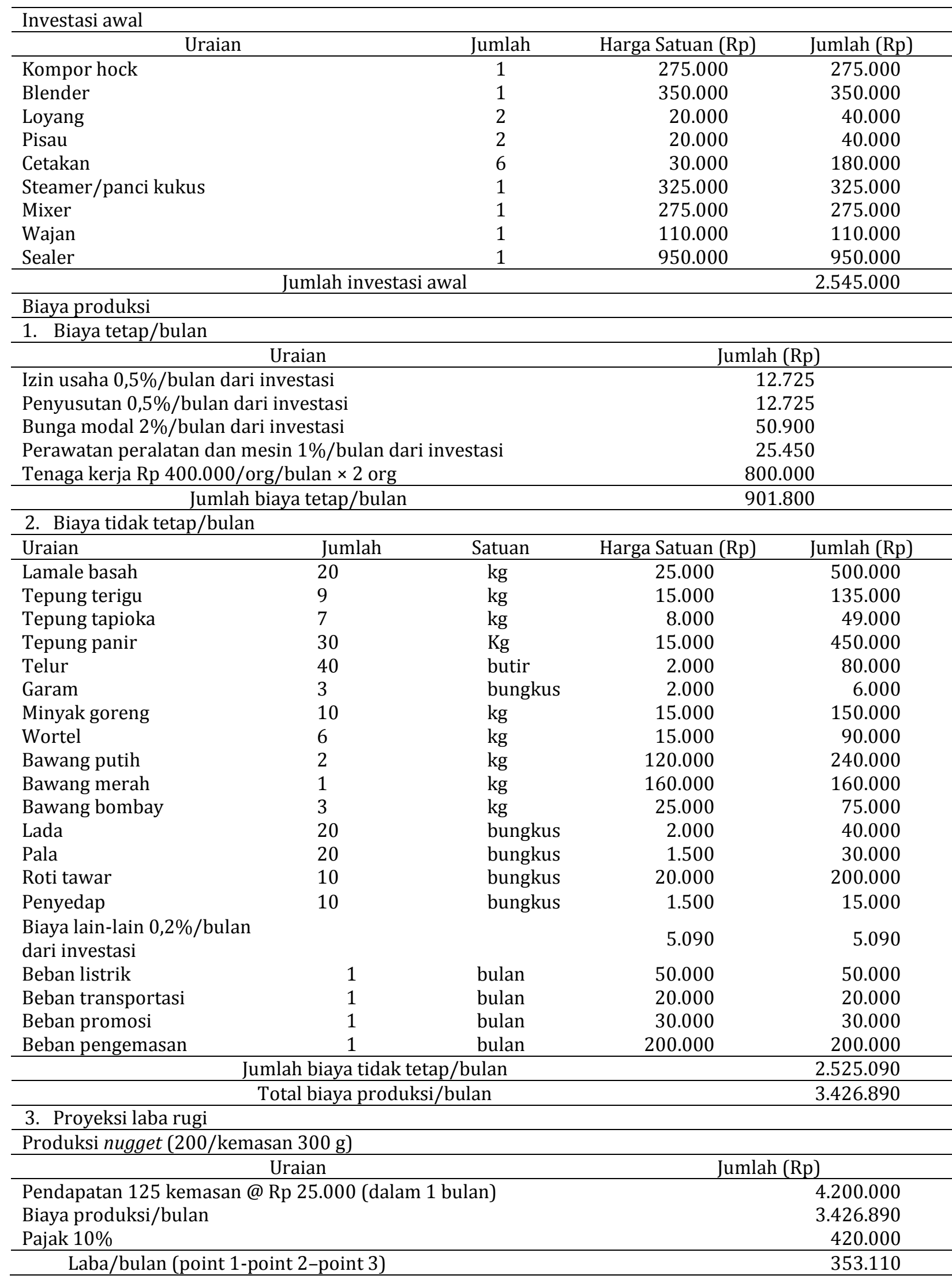

Hasil analisis nugget diketahui bahwa kadar protein memenuhi standar SNI. Kedua produk sama-sama menghasilkan kadar serat yang baik, berdasarkan standar SNI. Kulit udang lamale mengandung zat kitin yang bermanfaat bagi tubuh manusia dalam pembentukan rambut dan kuku yang baik. 

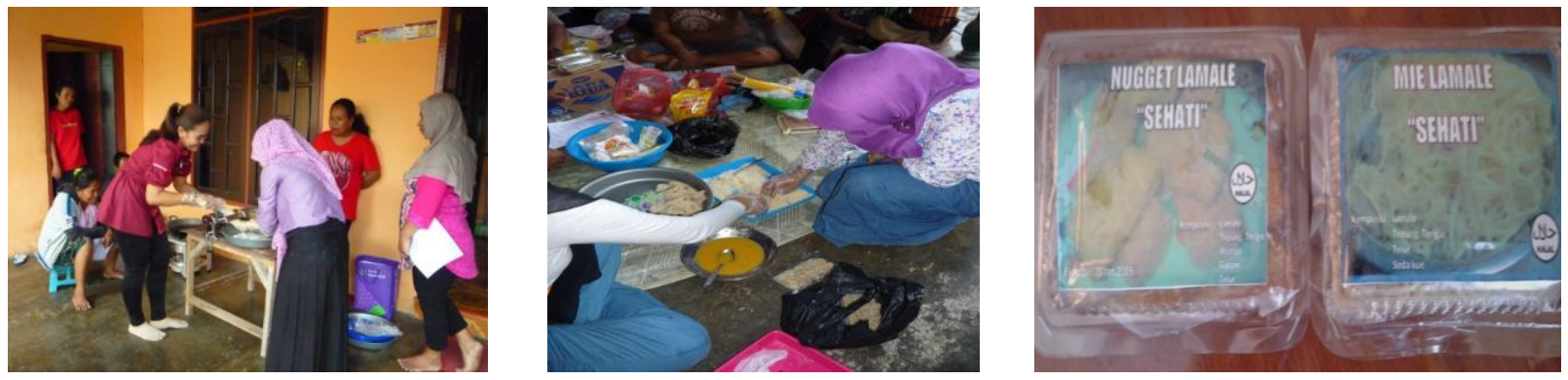

Gambar 3 Pelatihan pembuatan produk olahan lamale.

Tabel 4 Komposisi kimia mi dan nugget udang lamale

\begin{tabular}{lccccc}
\hline \multicolumn{1}{c}{ Kriteria } & Mi* & SNI mi basah & Nugget* & SNI nugget ayam & Satuan \\
\hline Kadar air & 3,79 & Maks. 35 & 10,61 & Maks. 60 & $\%$ \\
Lemak & 10,27 & - & 2,95 & Maks. 20 & $\%$ \\
Protein & 13,84 & Min. 8 & 16,38 & Min. 12 & $\%$ \\
Serat & 3,27 & - & 4,94 & - & $\%$ \\
Kadar abu & 1,71 & Maks. 3 & 4,01 & - & $\%$ \\
\hline
\end{tabular}

Sumber: SNI mi basah 01-2987-1992 dan SNI nugget ayam 01-6683-2002

Keterangan: *dianalisis di Laboratorium Nutrisi dan Makanan Ternak, Universitas Tadulako

\section{Tahap Pendampingan}

Tahap terakhir, yaitu tahap pendampingan manajemen usaha bertujuan agar mitra memahami pentingnya pengaturan keuangan usaha agar dapat berkembang dan mandiri. Materi yang diberikan berupa faktor-faktor yang memengaruhi usaha, yaitu cara menentukan harga sesuai dengan analisis kelayakan usaha yang telah dilakukan dan faktor-faktor yang harus dimasukkan agar harga jual memberikan keuntungan bagi mitra. Selain itu, diberikan pelatihan pembuatan pembukuan sederhana agar pengeluaran dan pendapatan pribadi tidak tercampur dengan usaha (Sugiono 2009). Peserta terdiri dari anggota kedua kelompok mitra. Mitra mengikuti pelatihan dengan serius mengingat pentingnya materi untuk menentukan harga dan pencatatan pendapatan dan pengeluaran agar mitra tidak rugi.

Selain itu, tim juga memperlihatkan kepada kedua mitra contoh-contoh produk mi dan nugget yang beredar di pasaran untuk membuka wawasan mitra. Selain mempelajari masalah pengolahan, kedua mitra juga mempelajari sanitasi dan higiene pengolahan yang baik dan benar dengan memerhatikan keamanan pangan (Nuraida 2008). Mitra diharuskan mencuci tangan sebelum memulai pengolahan, wajib menggunakan celemek, dan masker selama melakukan pengolahan. Bahan-bahan yang akan digunakan dicuci dengan air mengalir terlebih dahulu. Bahan tambahan pangan yang digunakan harus yang termasuk kelompok food grade.

Produksi mi dan nugget lamale masingmasing rata-rata sebanyak 120 produk/bulan dan 175 produk/bulan mampu dilakukan oleh mitra secara kontinu. Berat tiap kemasan untuk mi $800 \mathrm{~g}$ dan nugget $300 \mathrm{~g}$. Seluruh pengeluaran biaya produksi yang dibutuhkan selama kegiatan mampu dicatat dengan baik dalam pembukuan. Produk kemudian dijual pada konsumen di gerai atau kios milik anggota kelompok mitra. Transaksi penjualan mampu dicatat dengan baik dan kemudian kedua mitra dapat melakukan perhitungan dan pencatatan pada buku laba/ rugi, artinya bahwa mitra telah mengetahui besar keuntungan ataupun kerugian yang diterima selama melakukan kegiatan produksi. Beberapa kendala dalam pelaksanaan yang dihadapi mitra dibalik kemampuannya, adalah mitra masih melakukan pencatatan pembukuan secara manual, hal ini dilatarbelakangi oleh keterbatasan pengetahuan yang dimiliki oleh mitra. Keterbatasan lemari pendingin/pembeku juga dikarenakan modal usaha yang belum memadai guna pengembangan usaha. Walaupun mitra telah mengetahui dengan baik suhu penyimpanan yang aman untuk produk mi dan nugget. Tim juga membekali mitra dengan pelatihan pelabelan agar mitra memahami isi yang harus ada pada label (sesuai dengan PP 69 Tahun 1999 tentang Label dan Iklan Pangan). Tim telah memfasilitasi label baru untuk mempermudah mitra, walaupun isi label belum sepenuhnya sesuai dengan peraturan pelabelan. Hal ini karena izin edar mitra belum keluar dari dinas kesehatan setempat.

Upaya keberlanjutan kegiatan diarahkan pada kegiatan pendampingan dan pembimbingan secara kontinu untuk mengatasi kendala yang 
dihadapai mitra. Selain itu, juga dilakukan peningkatan pengetahuan mitra dalam melakukan usaha dan membantu mitra dalam pembuatan proposal usaha berdasarkan studi kelayakan agar memperoleh tambahan modal usaha baik dari bank maupun pemerintah daerah. Diharapkan kedepan kedua kelompok mitra nelayan tangkap lamale di Kelurahan Lere mampu mandiri secara ekonomi dan menjadi contoh bagi masayarakat setempat dalam peningkatan nilai tambah produk perikanan yang selama ini hanya di pasarkan dalam bentuk segar maupun kering.

\section{SIMPULAN}

Kedua mitra telah mengetahui prospek usaha penjualan mi dan nugget lamale, telah memiliki pengetahuan membuat mi dan nugget lamale, telah mengetahui manajemen mutu dan sanitasi dalam pengolahan yang baik, telah mengetahui kandungan gizi mi dan nugget lamale, telah dapat mengelola usaha penjualan mi dan nugget lamale, dan telah dapat memasarkan produk yang berorientasi profit. Secara umum tujuan telah tercapai tetapi konsistensi dari segi kualitas produk yang perlu ditingkatkan, serta pembukuan sederhana yang menurut tim masih sering lupa dicatat.

\section{UCAPAN TERIMA KASIH}

Kepada Direktorat Riset dan Pengabdian Kepada Masyarakat Kementerian Riset Teknologi dan Pendidikan Tinggi, Ketua Sekolah Tinggi Perikanan dan Kelautan (STPL) Palu, Kepala Lembaga Penelitian dan Pengabdian pada Masyarakat STPL Palu, Pemerintah Kelurahan Lere atas partisipasinya dalam memfasilitasi sehingga kegiatan pengabdian pada masyarakat ini dapat terlaksana.

\section{DAFTAR PUSTAKA}

Amri K, Kanna I. 2008. Budi daya Udang Vaname Secara Intensif, Semi Intensif, dan Tradisional. Jakarta (ID): Gramedia Pustaka Utama.

Anggo AD, Swastawati F, Ma'ruf WF, Rianingsih L. 2014. Mutu Organoleptik dan Kimiawi Terasi Udang Rebon dengan Kadar Garam Berbeda dan Lama Fermentasi. Jurnal Pengolahan Hasil
Perikanan Indonesia. 17(1): 53-59. https://doi.org/10.17844/jphpi.v17i1.8137

Astawan M. 1999. Membuat mi dan bihun. Jakarta (ID): Penebar Swadaya.

[BPS] Badan Pusat Statistik Kota Palu. 2010. Kota Palu dalam angka. Palu (ID). Badan Pusat Statistik.

[BSN] Badan Standardisasi Nasional. 2002. Nugget Ayam. SNI No. 01-6683-2002. Jakarta.

[BSN] Badan Standardisasi Nasional. 1992. Mi Basah. SNI No. 01-2987-1992. Jakarta.

[DKP] Dinas Kelautan dan Perikanan Propinsi Sulawesi Tengah. 2010. Laporan Statistik Perikanan Tangkap Tahun 2009. Palu (ID). Dinas Kelautan dan Perikanan Propinsi Sulawesi Tengah.

Firdaus M. 2008. Manajemen Agribisnis. Jakarta (ID): Bumi Aksara.

Hanifah. 2015. Strategi Pengembangan Usaha Udang Lamale di Kelurahan Lere Kecamatan Palu Barat. [Tesis] Palu (ID): Universitas Tadulako.

Kanangadju M, Yalirante P, Likenono G, Likenono L, Lasipi T. 1989. Percakapan Sehari-hari Dalam Bahasa Da'a. Ujung Pandang (ID): Universitas Hasanuddin, Universitas Tadulako, dan Summer Institute of Linguistics.

Mardjudo A. 2011. Analisis Hasil Tangkapan Sampingan (By-Catch) dalam Perikanan Pukat Pantai Jenis Krakat Di Teluk Kota Palu Sulawesi Tengah. Jurnal KIAT Universitas Alkhairaat. Desember: 6-16.

Muhamadjen E. 2008. Analisis Kelayakan Usaha Kapsul Ekstrak Di Taman Sringganis Bogor. [Skripsi] Bogor (ID): Insitut Pertanian Bogor.

Nuraida L. 2008. Keamanan Pangan Industri Usaha Kecil dan Menengah (UKM) Dan Industri Rumah Tangga (IRT) Pangan. Disampaikan pada pra-WNPG (Widyakarya Nasional Pangan dan Gizi) IX. Jakarta, 17 Juni 2008.

Soekartawi. 2002. Agribisnis (Teori dan Aplikasi). Jakarta (ID): Raja Grafindo Persada.

Sugiono A. 2009. Manajemen Keuangan untuk Praktisi Keuangan. Jakarta (ID): Grasindo.

Sundari MT. 2011. Analisis Biaya dan Pendapatan Usaha Tani Wortel di Kabupaten Karanganyar. SEPA. 7(2): 119-126. 